DOI: 10.17746/1563-0110.2019.47.4.066-076

\author{
K.A. Kolobova ${ }^{1}$, A.Y. Fedorchenko', N.V. Basova', \\ A.V. Postnov ${ }^{1}$, V.S. Kovalev ${ }^{1}$, P.V. Chistyakov ${ }^{1}$, and V.I. Molodin ${ }^{1,2}$ \\ ${ }^{1}$ Institute of Archaeology and Ethnography, \\ Siberian Branch, Russian Academy of Sciences, \\ Pr. Akademika Lavrentieva 17, Novosibirsk, 630090, Russia \\ E-mail:kolobovak@yandex.ru; winteralex2008@gmail.com; bass15@yandex.ru; postnov@yandex.ru; \\ vasiliy.s.kovalev@gmail.com; pavelchist@gmail.com; \\ molodin@archaeology.nsc.ru \\ ${ }^{2}$ Novosibirsk State University, \\ Pirogova 1, Novosibirsk, 630090, Russia
}

\title{
The Use of 3D-Modeling for Reconstructing the Appearance and Function of Non-Utilitarian Items (the Case of Anthropomorphic Figurines from Tourist-2)
}

This article presents the results of study of an Early Bronze ivory figurine from Tourist-2, using 3D-scanning with various technical parameters. The aim of the study was to test the new non-invasive methods of structured light $3 D$-scanning, with an accurate assessment of morphometric characteristics. In addition, use-wear analysis was employed to evaluate the previously unknown features relating to function. As a result, the original appearance of the figurine, the manufacturing technique, and iconographic characteristics were reconstructed. A series of transverse sections and the evaluation of the center of mass, combined with previously known features, suggest that the figurine was a personal ornament sewn onto clothing. For comparison, two flat anthropomorphic sculptures (a buckle made of burl, and a shale figurine) from the same burial complex were analyzed. Longitudinal sections suggest that, despite morphological and technological differences and the fact that various raw materials had been used, the iconographic style of all items is one and the same.

Keywords: Bronze Age, Krokhalevka culture, anthropomorphic sculpture, iconographic style, 3D-modeling, usewear analysis.

\section{Introduction}

The development of archaeological science in recent years is determined by mainstreaming new methods and technologies. 3D-modeling, which can be used both as an independent research tool and in concert with conventional methods, occupies a prominent place in this process. One of the main and undeniable advantages of using 3D-modeling of archaeological artifacts as a part of scanning (as compared to trace-drawing, photography, and photogrammetry) is the possibility of the relatively quick creation of high-quality scale models. However, the use of this method is not limited to visualization, and offers many new opportunities for obtaining verifiable results.

First efforts to study artifacts by means of digital models were made as early as the end of the 20th century (Wood, Chapman, 1992; Levoy et al., 2000). Since then, modeling with the use of structured-light 3D-scanners has become a widespread tool for visualization and study of historical and cultural values (Mcpherron, Gernat, Hublin,

Archaeology, Ethnology \& Anthropology of Eurasia 47/4 (2019) 66-76 E-mail: Eurasia@archaeology.nsc.ru (C) 2019 Siberian Branch of the Russian Academy of Sciences

(C) 2019 Institute of Archaeology and Ethnography of the Siberian Branch of the Russian Academy of Sciences (C) 2019 K.A. Kolobova, A.Y. Fedorchenko, N.V. Basova, A.V. Postnov, V.S. Kovalev, P.V. Chistyakov, V.I. Molodin 


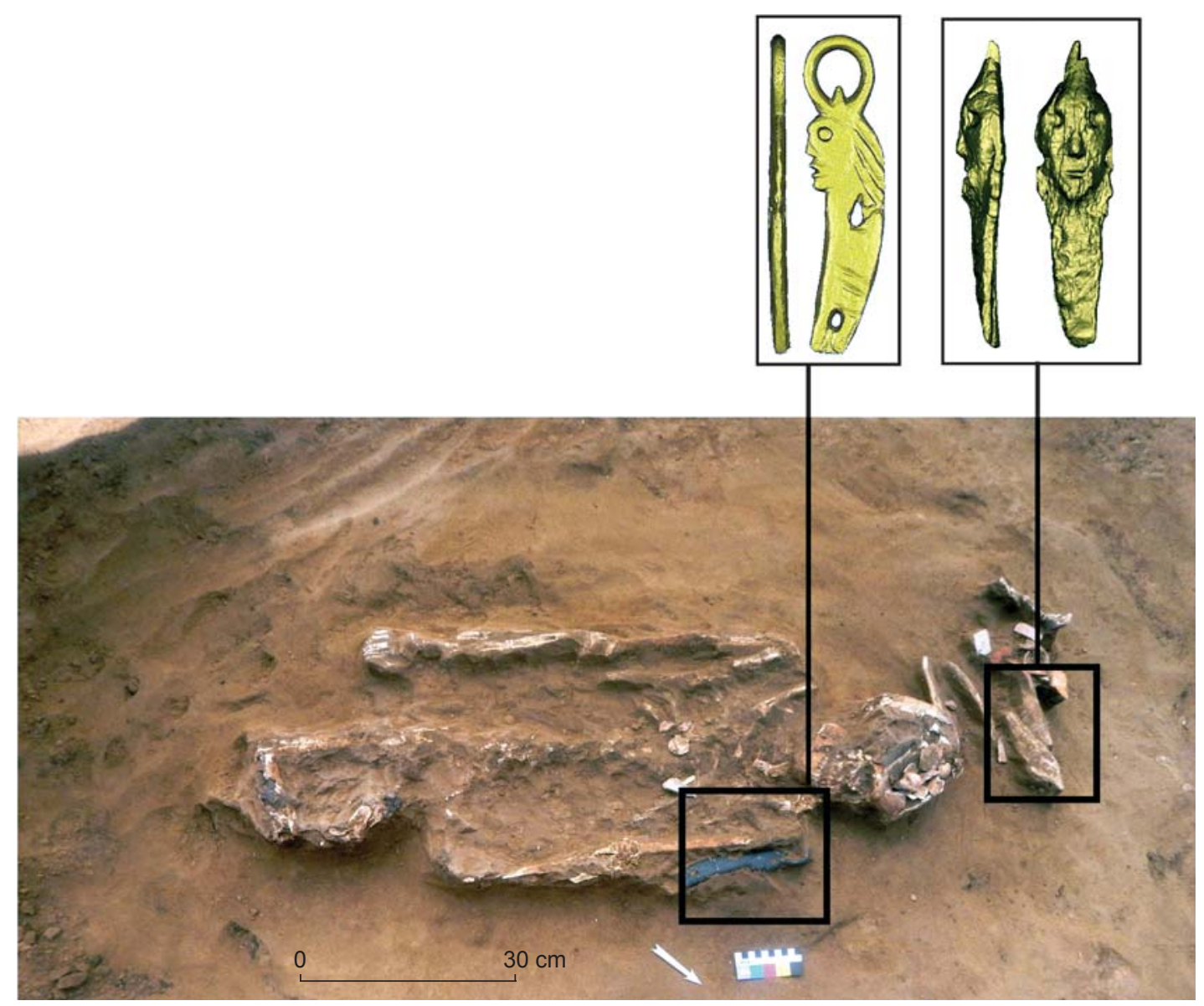

Fig. 1. Location of anthropomorphic figurines in burial 5.

2009; Counts, Averett, Garstki, 2016). For the study of artifacts of the Bronze and Iron Ages, 3D-modeling is already used as a conventional method (Karasik, Smilansky, 2008).

$3 \mathrm{D}$-modeling is widely used in the study of petroglyphs. Analysis of 3D-models allows not only the documenting and storing of items, but also the obtaining of new information as a result of the discovery of earlier invisible drawings, stratification of images superimposed on one another, and determination of their application technologies (Grimaud, Cassen, 2016; Devlet et al., 2017; Zotkina, 2019; Zotkina, Kovalev, 2019).

A special area for using new technologies is the study of unique non-utilitarian items. No generally accepted protocol for the study of these items has been created so far owing to differences in their morphology and functions (Counts, Averett, Garstki, 2016; Grosman et al., 2017; Morris, Peatfield, O'Neill, 2018). The most spectacular example of such research is the establishment of the functions of masks from the Levantine Neolithic assemblages, which resulted in a conclusion about the post-mortem type of these items (Grosman, Ovadia, Bogdanovsky, 2014).
This article presents the experiences of the first Russian archaeological study aimed at reconstructing, on the basis of 3D-scanning methods, technological and experimental use-wear analyses, the appearance, function, manufacturing technique, and iconographic characteristics of anthropomorphic figurines.

\section{Study materials}

The object of our study is an ivory anthropomorphic figurine from burial 5 of Tourist-2 (Novosibirsk), a cemetery from the Early Bronze Age (Basova et al., 2017). In order to perform cultural and stylistic interpretations, we involved two other anthropomorphic figurines from this burial complex: a buckle made of burl (a tree growth with deformed wood grains) found in the same burial, and a shale figurine from burial $6^{*}$.

*See the location of site, description and representations of the anthropomorphic figurines under consideration in the article by N.V. Basova, A.V. Postnov, A.L. Zaika, and V.I. Molodin, in this issue of the journal. 
In the burial, at a depth of $0.8 \mathrm{~m}$ below the daylight surface, the skeleton of a 40-45-year-old man was found, in an extended supine position, with his head towards the north. The small bones of feet and hands were absent. Northwest of the skeleton, a fragment of the right side of the mandible of a 20-25-year-old man (definitions made by a Junior Researcher of the IAET SB RAS, M.S. Kishkurno) was recorded. Between this fragment and the skull of the adult man, there was an accumulation of artifacts, including two polished stone knives, flakes, beaver's incisors, bone items, and the anthropomorphic figurine to be analyzed (Fig. 1). The artifact under study had been partially destroyed, owing to natural fracturing and exfoliation of the tusk over its cone-like structure. During conservation and restoration works, the find was glued together, though small surface areas near the head proved to be lost. A buckle made of burl was lying parallel to the humerus of the full skeleton (Fig. 1). The third figurine under consideration was located in grave 6 , just above the pelvic bones of a buried adult man (Ibid.).

\section{Study methods}

All three anthropomorphic figurines from the Tourist-2 burial complex were subjected to 3D-scanning with the use of structured-light technique (Fig. 2). The method consists in projecting the sets of light strips onto a scanned item, using a video projector, wherein the light strips are recorded by high-precision digital cameras. On the basis of transformations of a strip sample with the use of software, a 3D-grid of the item's surface is calculated.

A Thor Drake 3D-scanner with a resolution of $0.15 \mathrm{~mm}$ and accuracy of 3D-point (root-mean-square deviation) of $0.04 \mathrm{~mm}$ was used for 3D-scanning of the ivory anthropomorphic figurine (model No. 1). 3D-models of two other items were obtained using a Rangevision Pro $5 \mathrm{M} 3 \mathrm{D}$-scanner. The resolution for the burl buckle (model No. 2) is $0.1 \mathrm{~mm}$, and for the anthropomorphic shale figurine (model No. 3) $0.04 \mathrm{~mm}$; the 3D-point accuracy is 0.03 and $0.018 \mathrm{~mm}$, respectively.

The 3D-scanning process comprises two steps: photographing and superimposition of 3D-images to form a single model (Chistyakov et al., 2019). 50 and $703 \mathrm{D}$-images, about $1.2-1.5 \mathrm{mln}$ points in each, were produced for models No. 2 and No. 3, respectively. Markers, i.e. special marks determined by software during scanning, were used in order to partly automate superimposition of 3D-images. The Thor Drake 3D-scanner employs a slightly different projection principle that consists in applying a grid and producing 3D-images with a higher rate, but a smaller number of points in each. Consequently, creation of a model of equal quality requires a greater number of photos. 3757
3D-photos, 2000-5000 points in each, were taken for model No. 1. After combination of images, we obtained polygonal 3D-models with the following parameters: No. $1-972,848$ polygons, No. $2-1,292,650$ polygons, and No. $3-3,194,026$ polygons.

Subsequent processing of models was carried out with Autodesk Netfabb and Meshmixer software. This provides for the following: first, to fill empty areas in a 3D-model automatically on the basis of interpolation of coordinates of the area end-points, thus reconstructing the initial surface approximately; second, to rectify errors of the polygonal model, such as self-intersections, small spines, islets, etc. All manipulations with models (determination of the item's center of mass and crosssection, calculation of volume) were performed by this program.

The geometric point of applying the total gravitational force acting on the particles of a body at any position of the latter in space is called center of gravity. The center of gravity of a solid in a uniform gravitational field coincides with the position of its center of mass. Calculation of the center of gravity of a 3D-model is conducted assuming that it is a uniform body. In such a case, the center of gravity will be the geometric center of the model (barycenter or centroid). The barycenter's coordinates are calculated as the arithmetic mean of the coordinates of all the 3D-model's points, or by the method of partitioning into a finite number of parts: for example, tetrahedrons. The last method is suitable, since each triangle of the polygonal model's surface will correspond to a tetrahedron face, while the fourth apex will lie normal to this polygon; the coordinates of the center of volume for each part are calculated from the apex's coordinates (Ponarin, 2009: 36). The total body volume equals to the sum of the component volumes:

$$
V=\sum V_{i}
$$

Coordinates of the body center of gravity are determined from the following formulas:

$$
\begin{aligned}
& x_{c}=\left(\sum v_{i} x_{i}\right) / v, \\
& y_{c}=\left(\sum v_{i} y_{i}\right) / v, \\
& z_{c}=\left(\sum v_{i} z_{i}\right) / v,
\end{aligned}
$$

where $x_{i}, y_{i}, z_{i}$ are coordinates of the centers of gravity of the components (Targ, 1986: 38-39).

Reconstruction of the missing elements of model No. 1 was performed by the method of mirror reflection of the corresponding elements (taking into account an assumption concerning the symmetry of these elements) and partial sculpting using the Autodesk Meshmixer software package. The integrated study included experimental use-wear and technological analyses of the anthropomorphic sculptures. To reconstruct ancient technologies for processing of raw materials, several 


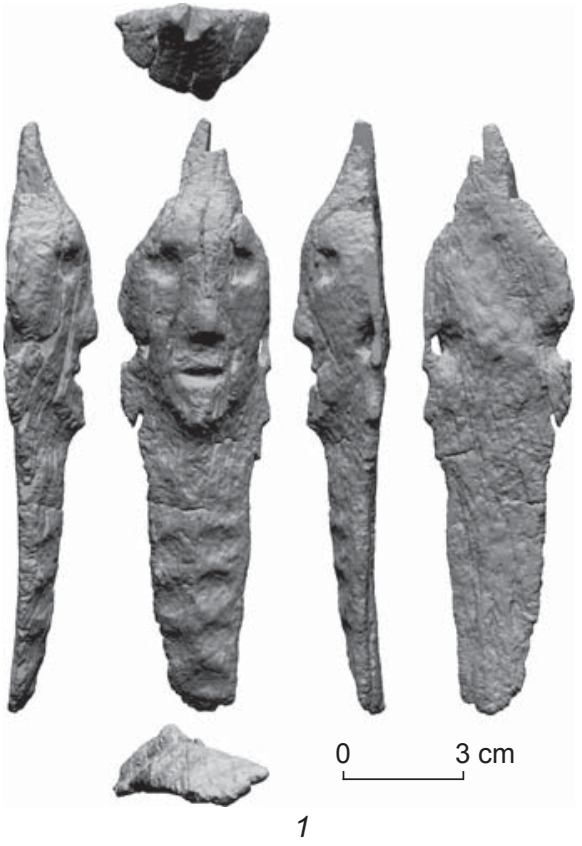

Fig. 2. 3D-models of anthropomorphic figurines made of mammoth tusk (1), shale (2), and burl (3).

specialized scientific procedures were performed: analysis of the technological context, the specific shapes and technological order of the item's production, treatment techniques, tools in use, types and sources of raw materials, experimental modeling of various methods and technologies of treatment (White, 2007; Khlopachev, Girya, 2010: 7-38).

Experimental use-wear analysis was employed to reconstruct the functions, purposes, and methods of manufacture of ancient artifacts. It included two interrelated scientific procedures: study of the working surfaces of tools in order to reveal, analyze, and record the wear/treatment marks; and physical modeling of the processes of the manufacture of replicas of ancient artifacts to produce reference samples. Analysis of traces was carried out at low $(\times 7-45)$ magnification, using the binocular microscope Altami CM0745-T with oblique illumination. Photographic fixation of them was performed by a Canon EOS 5D Mark IV mirror chamber with Canon EF $100 \mathrm{~mm} \mathrm{f} / 2.8 \mathrm{~L}$ Macro IS USM and MP-E $65 \mathrm{~mm}$ F2.8 1-5X Macro lenses, and a tripod mount with manual focus adjustment. Photographs with focusing in the entire area of one frame were obtained with the Helicon Focus program. Interpretation of various categories of traces included experimental data from the published sources (Khlopachev, Girya, 2010: 39101; Heckel, Wolf, 2014; Steguweit, 2015; Hein, 2018) and the results of our own experimental observations. The employed study model was tested by the authors
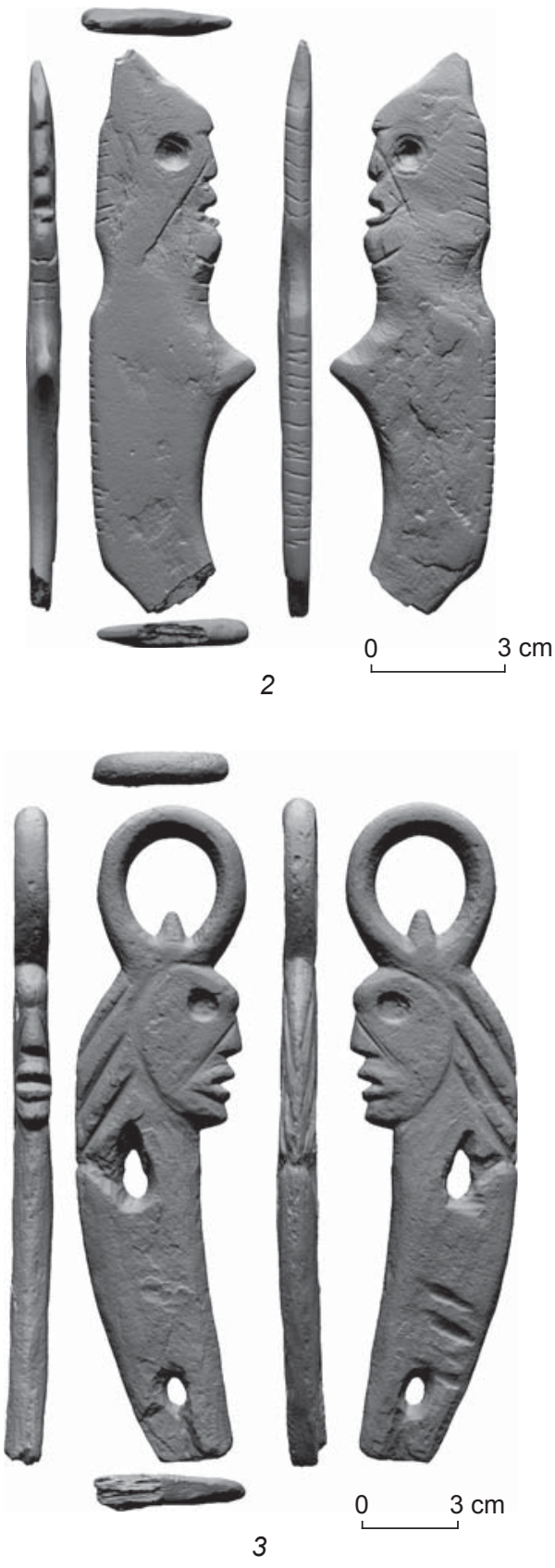

in the analysis of bone artifacts from the Paleolithic sites of Altai (Shunkov, Fedorchenko, Kozlikin, 2017; Derevianko et al., 2018).

\section{Results of the study}

We have determined the state of preservation of the analyzed ivory anthropomorphic figurine to be satisfactory. Use-wear analysis has shown that treatment and wear marks on the artifact are not fully preserved, as they were deformed owing to exfoliation over tusk growth cones because of drying and surface erosion. 
Nevertheless, certain reduction in the informational value of this item didn't preclude our performing all the scientific procedures required to establish the purpose and production technology of the artifact.

The analysis of treatment marks, morphometric and raw-material features of the ivory anthropomorphic sculpture suggests a rather specific technological order aimed at producing elongated, massive spalls. Source raw materials were obviously found in the fossil condition, since the last woolly mammoths (Mammuthus primigenius) disappeared from the major part of Siberia at the end of the Late Pleistocene (MacDonald et al., 2012). In the Early Metal Age in Western Siberia, the mammoth tusk could have been acquired in the bank exposures of river valleys (Borodovsky, 1995; Borodovsky, 2012: 33).

Treatment of fossil ivory raw materials was stagially preceded by releasing the tusk dentin body from the surface cement layer. The next stage was production of the initial base spall. Traces of primary treatment on the artifact's surfaces have been lost, owing to strong modification of its morphology at the subsequent stages of manufacture of the anthropomorphic figurine. The morphometric parameters (massiveness and large length) and special features of the artifact's orientation relative to the tusk's laminated structure suggest that the blank probably had a rod-like shape and a wide V-shaped cross-section. Such morphology points to production of an elongated spall by deep longitudinal cutting out or adzing, with subsequent breaking of a pre-wetted tusk (Khlopachev, Girya, 2010: 29).

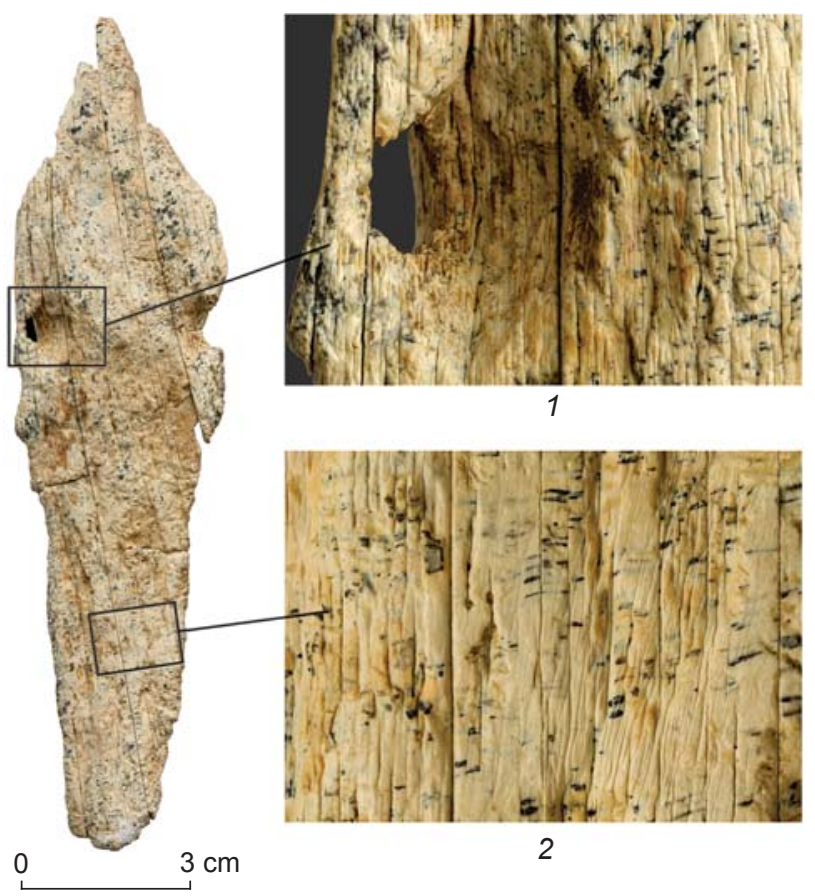

The reduction variant under consideration could have been implemented both along the predetermined grooves and without them. In the last case, the role of grooves initiating the process of producing elongated rod-like blanks could have been played by deep longitudinal cracks on the tusk's surface, which were typical of the fossil ivory. According to data from A.P. Borodovsky, heavy-duty metal tools were widely used for the primary treatment of mammoth tusks in the Bronze and Early Iron Ages (1997: 108-109). During detachment of elongated spalls from the tusk body, a system of wedges and levers was obviously employed.

At the next stage, blank surfaces were treated by slicing, probably in a wetted state as well. Traces of slicing with a metal tool with a relatively straight blade are preserved on the ventral side of the item (Fig. 3, 2). At $\times 10-45$ magnification, they have the appearance of lengthy, winding furrows going diagonally relative to the long axis of the artifact. Slicing was used to level the surface and to shape the outlines of the face and headdress.

The next stage of manufacture of the anthropomorphic figurine involved fashioning the facial features using various tools. Both eyes are rendered by blind holes carved with a tool with a U-shaped blade, such as an oval chisel (Fig. 4). The type of the mouth's cross-section suggests that is was shaped with the same tool with a V-shaped cross-section that had been used for treatment at the previous stage (Fig. 5).

A metal knife with a sharp-pointed blade was likely also used for the subsequent manufacture of two

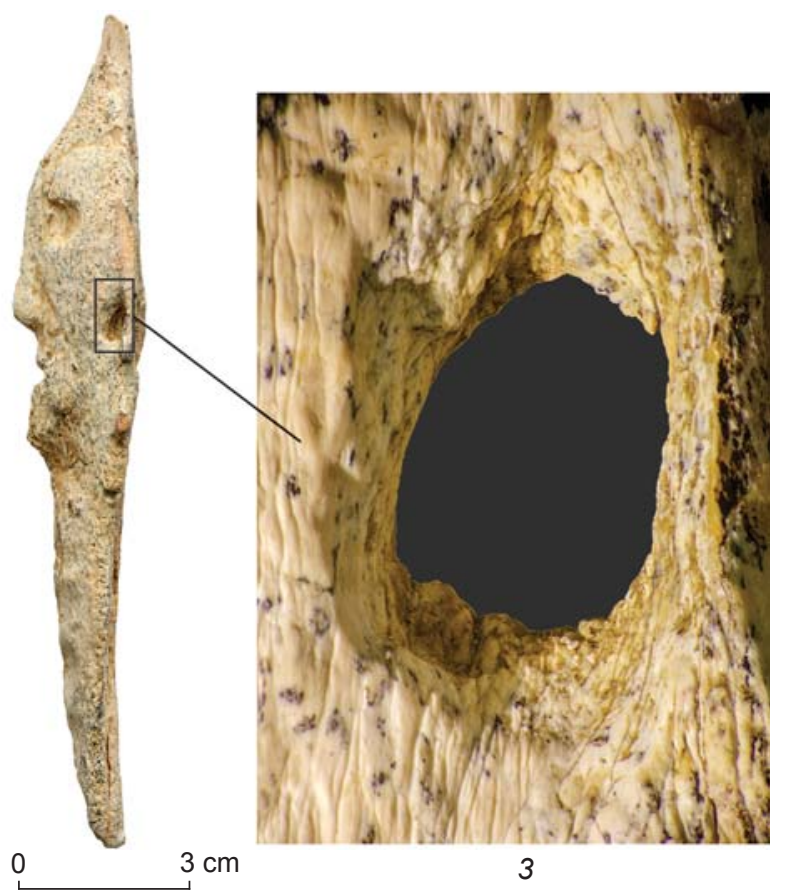

Fig. 3. Shaping of biconical through holes from the rear (1) and face (3) sides, and marks of slicing on the artifact's surface (2). 


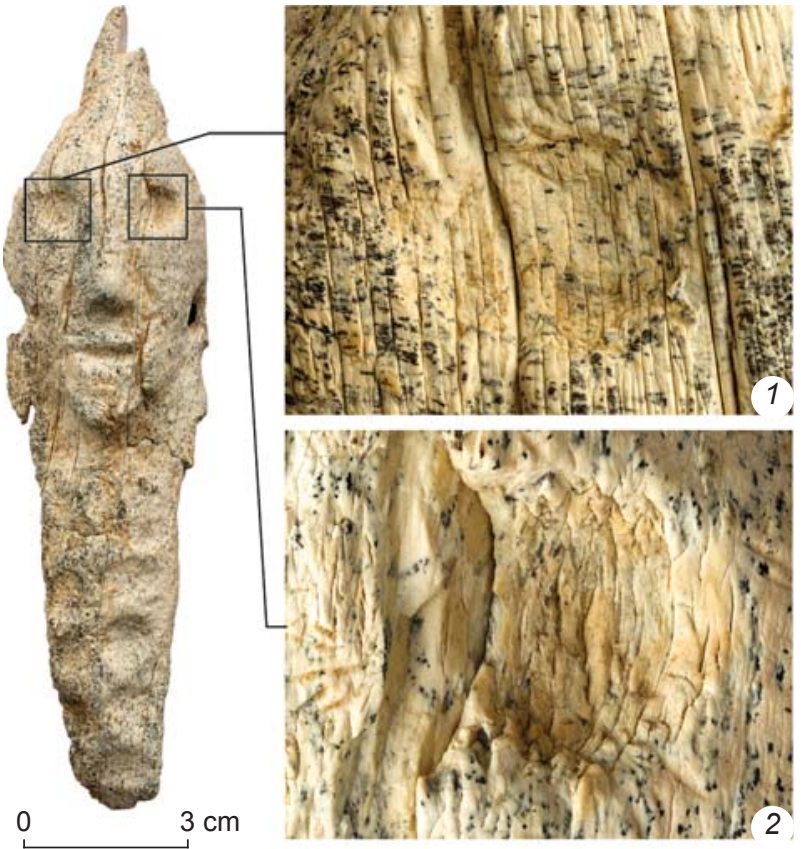

Fig. 4. Shaping of eyes using a tool with a U-shaped blade.

biconical holes at the edges of the item, one of which is fully preserved. Inside this hole, marks typical of cutting through are recorded (see Fig. 3, 1, 3). First, a through hole in the form of a wide oval truncated cone was formed on the ivory blank on its ventral side. Then, it was broadened on the opposite side in the reverse direction. There are no traces of leveling the hole's passage by additional boring.

The state of preservation of the sculpture's surfaces gave no means of revealing use-wear traces inside the holes. Nevertheless, owing to the use of 3D-modeling tools, consistent data regarding the functions of the analyzed artifact were obtained. With the help of the 3D-model we made a longitudinal section, which let us see the profile of the intact right hole (Fig. 6, 2). Such a visualization can be obtained only by $3 \mathrm{D}$-modeling, using scanning or photogrammetry.

The use of 3D-modeling offered the possibility of determining the item's center of gravity, which is visualized in the form of red circle on the model (Fig. 6, 1). It is located below symmetrical side holes (an intact and a fragmented), equally spaced from these. Such a position of the center of mass, coinciding with the center of gravity, ensured the stability of the sewed-on sculpture, though the elongated item was attached to the clothing at two points only. During wearing, the upper part of the figurine could not incline forward. The physical properties of the item guaranteed its strictly vertical position. This fact is an additional argument for the high-class skill of the artisan who manufactured this figurine and provided for its comfortable use.

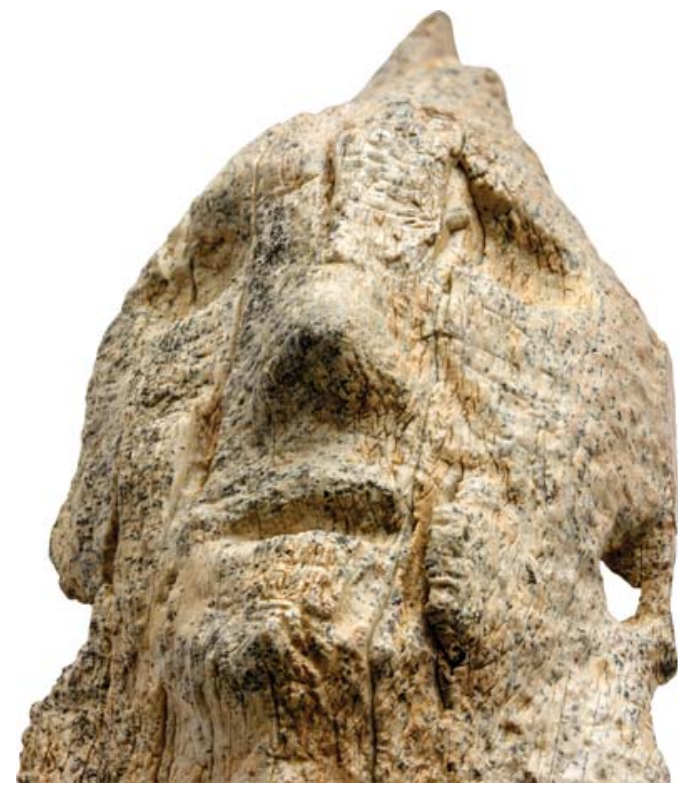

Fig. 5. Face of the sculpture: shaping of nose and mouth.

The employed method of mirror reflection allowed the missing parts of the analyzed sculpture to be reconstructed, including the left hole for fastening (Fig. 7). $0.7 \%$ of the item's volume was replenished. As a result of reconstruction, measurements of drilled holes and their comparison became possible (Fig. 8, 2). The axes of these holes intersect at the point corresponding to the longitudinal plane of the sculpture's symmetry (Fig. 8, 1). Such a direction is typical for the items that were attached to the clothing by two relatively thin straps or threads (Dayet et al., 2017: 642-643; Fedorchenko, 2018: 120).

\section{Discussion}

Ivory was one of the most in-demand organic fabricating materials, and was exceptionally widely used in Northern Eurasia to create various formal tools, personal ornaments and objects of art, starting in the Early Upper Paleolithic (Petrin, 1986: 82; Makarov, 2013; Pitulko, Pavlova, Nikolskiy, 2015; Sinitsyn, 2016; Shunkov, Fedorchenko, Kozlikin, 2017; Krivoshapkin et al., 2018). In the Holocene, the developed technologies of ivory-treatment continued their existence in the Siberian Arctic, as indicated by materials from the Mesolithic site on Zhokhovo Island in the East Siberian Sea and from the Rodinka Neolithic burial in the Lower Kolyma region (Girya, 2015; Kistenev, 1992).

Some of the most vivid examples of the manufacture of ivory anthropomorphic figurines in the Late Bronze Age in Siberia are recorded in the Glazkovo culture's 


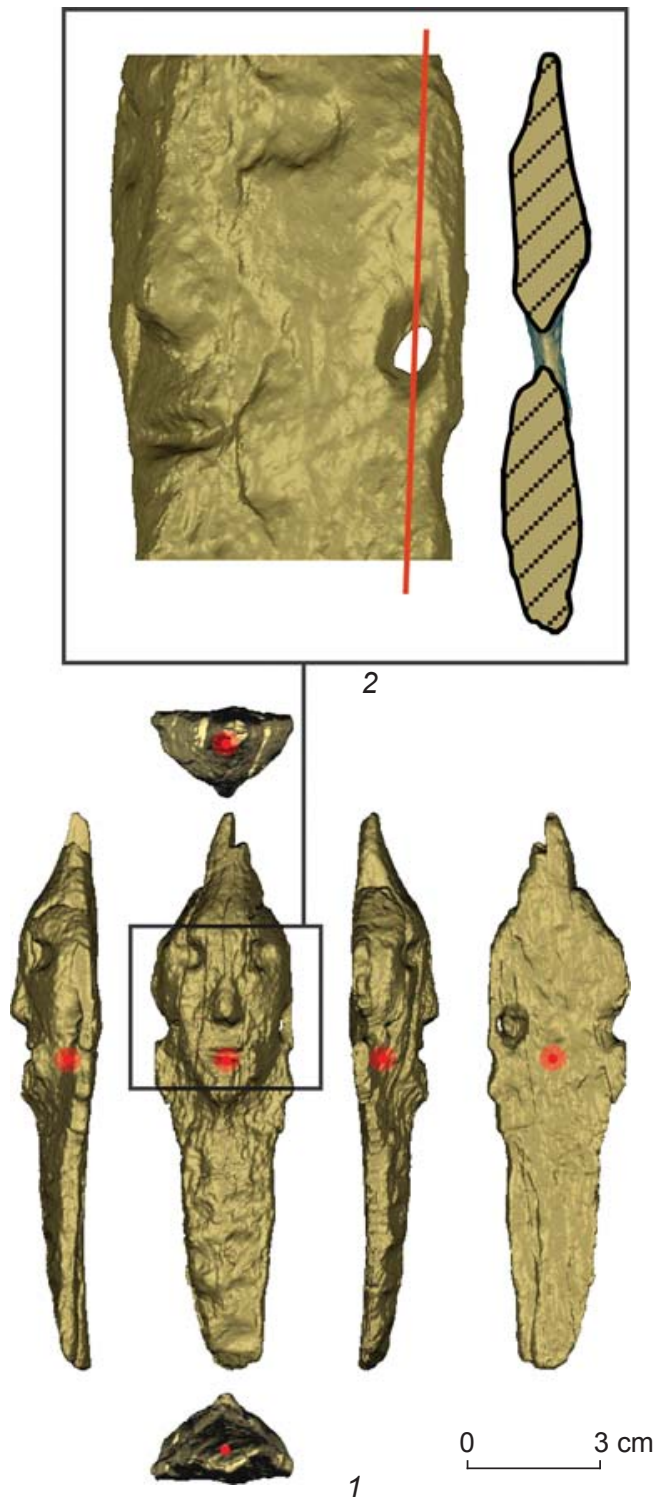

Fig. 6. Position of the figurine's center of mass (1) and a longitudinal section demonstrating biconical drilling (2).

burial complexes in Cis-Baikal region: the cemeteries of Ust-Uda (burial 4 and 6), Semenovsky (burial 4); Bratsky Kamen (burial 1), and Novy Kachug (burial 1) (Okladnikov, 1955: 285-287). Taking into consideration the object of our study, of special interest are two flat ivory figurines from the UstUda cemetery that represent images of a man and a woman. Four biconical holes are shaped in each of the humeral and femoral parts of these figurines (Ibid.: 286-287, fig. 139-140). The position of the figurines in the thoracic and abdominal regions suggest that these were attached to clothing. Another two flat ivory anthropomorphic figurines were discovered in the Late Bronze Age burial in the mouth of the Koda River, in the Northern Angara region (Drozdov, 1974). Later examples of ivory treatment in Western Siberia are recorded in the materials of the Ust-Polui sanctuary of the Early Iron Age in the mouth of the Ob River, and at the early medieval sites of Verkhne-Aksenovo-2, Sopka-1, and Kipo-Kulary (Borodovsky, 1997: 104111; Borodovsky, 2012). In certain areas of the Siberian North, the mammoth-tusks are used as a fabricating material up until the present day (Fedorov, 2017).

The first publication devoted to excavations of the Tourist- 2 cemetery emphasizes that the iconography of the artifacts discovered therein is typical of the Early and Middle Bronze Age cultures of Western Siberia (Okunev, Samus, Krotovo, Karakol, Odinovo, Elunino), manifestations of which are observed in the forest-steppe zone between the Irtysh and Yenisei rivers (Basova et al., 2017). For this reason, the range of analogs for the analyzed artifact is rather wide. From our point of view, the closest item is a sewed-on one-sided anthropomorphic plate (or buckle) found in an Early Bronze Age burial from the Korablik I cemetery, in northeastern lowland Altai (Grushin, Kokshenev, 2004: Fig. 4, 1). According to Y. F. Kiryushin and S.P. Grushin, this artifact is unique (2007: 25). Indeed, it does not have full analogs; however, the flat bas-relief image en face makes the proposed comparison quite appropriate.

Noteworthy is one more detail of all three analyzed anthropomorphic figurines from Tourist-2: namely, the pointed headdresses. Researchers repeatedly mentioned the occurrence of ray-like pointed headdresses on sacral images of the cultural and chronological stratum under consideration, which are especially typical of petroglyphs (see, e.g., (Kubarev, 1988: 36-37, 63), but are also observed on the Okunev ceramics (Pauls, 1997: Fig. 4) and portable objects of art (Grushin, Kokshenev, 2004: Fig. 4). The representations of tight-fitting caps (similar to the modern Svane caps) are inherent in the stone, metal, and bone sculptures of this period (Molodin, 2015). In view of the above, it may be cautiously suggested that pointed headdresses are typical of the Krokhalevka culture. Meanwhile, as we can see, images of "sunheaded" anthropomorphs (Basova et al., 2017: Fig. 2), an expression of epochal symbolism, are also usual in this culture. Pointed headdresses, though infrequent, are still encountered in the Okunev engravings (Lipsky, Vadetskaya, 2006) and, exceptionally, in the portable art of the Early Bronze Are in the Cis-Baikal region (Bazaliysky, 2007; Bobrov, 2015).

One more special feature of at least two of the figurines under consideration is the representation of long hair, which is most typical of the items made in the style of Okunev "Abakan plates" that depicted women with unfastened hair (Kovalev, 1997; Khavrin, 1997), and also with nose tattoos (Savinov, 2015). These obviously epochal features allow the concerned artifacts to be 


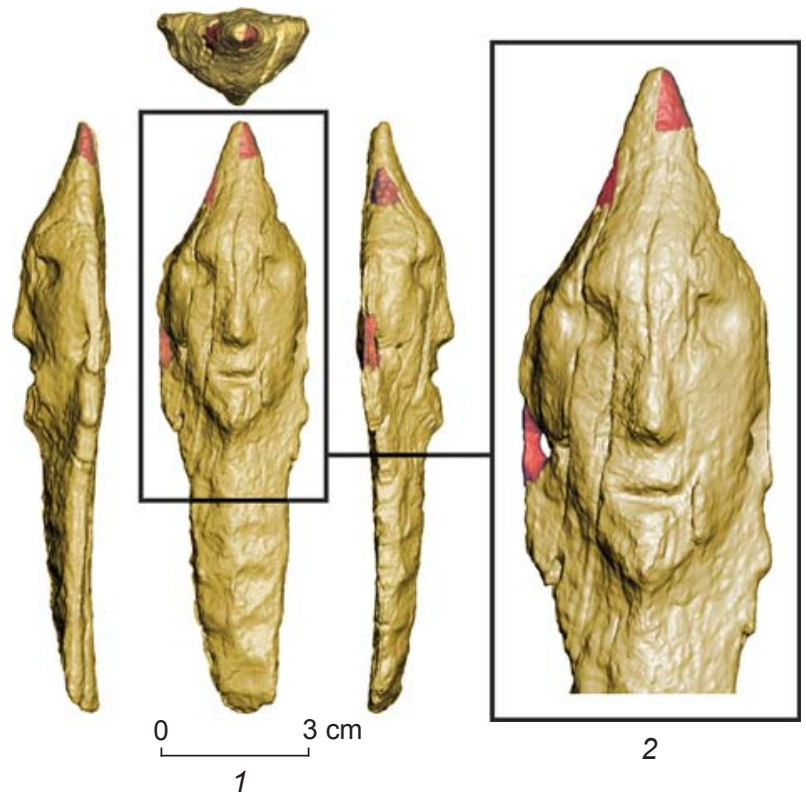

Fig. 7. Reconstruction of the initial appearance of the ivory anthropomorphic figurine.

included into a single circle of the Early to Middle Bronze Age cultures of Western Siberia.

Apparently, the iconography of all three figurines under consideration is very similar. Men with rounded eyes and massive noses, wearing pointed headdresses, are depicted. They are shown with open mouths, and full lips are performed in relief. To demonstrate the iconographic similarity, we obtained longitudinal sections in a relative scale, while working with 3D-models (Fig. 9).

Judging by the archaeologically intact vessels in the burials of the Tourist-2 cemetery, the site belongs to the Krokhalevka culture (Basova, 2018). Meanwhile, the complex is comparable exclusively to textile ceramics (Molodin, 1977: Tabl. LXIV, 1; LXVI, 3, 4).

\section{Conclusions}

The combination of 3D-modeling tools and technological and experimental use-wear methods has demonstrated their efficiency in the reconstruction of the technique of manufacture, function, and cultural and chronological interpretation of a unique ivory anthropomorphic sculptured image. In our opinion, 3D-modeling is an indispensable tool for the following scientific procedures:

1) Reconstruction of the initial appearance of an artifact. The symmetry of separate parts of the item to be reconstructed is an essential prerequisite. Such an approach is also used in reconstruction of the initial appearance of paleontological and anthropological remains (Freidline et al., 2012);

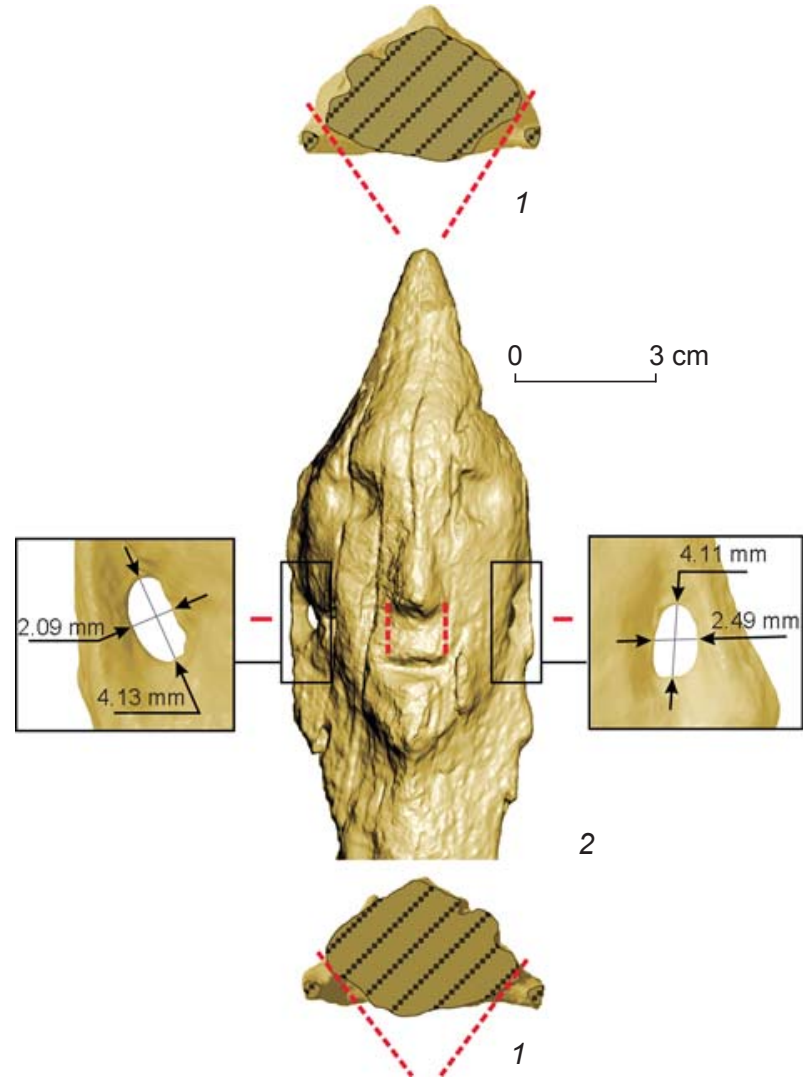

Fig. 8. Direction of the axes of symmetrical holes (1), and metric parameters of the existing and reconstructed holes (2).

Fig. 9. Longitudinal sections of the anthropomorphic figurines on a relative scale.

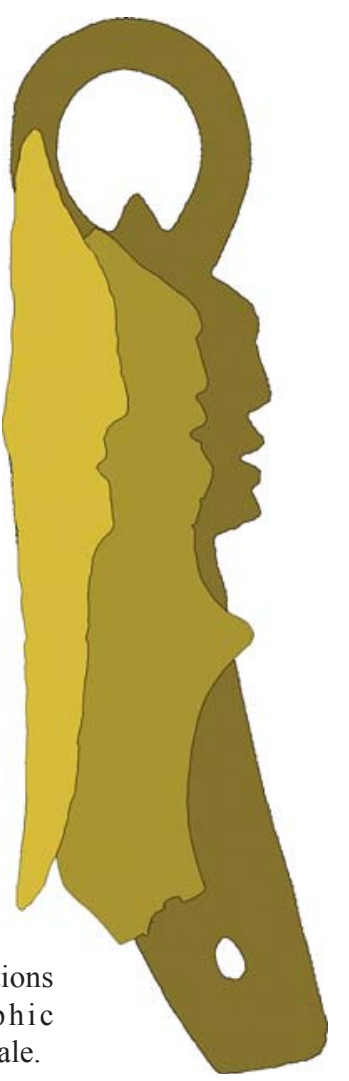


2) Non-invasive manipulations, in order to obtain sections and projections of artifacts;

3) Various metric and geometric calculations, such as determination of the main and specific metric parameters, volume (with the possibility of subsequent calculation of the mass, with the known density of raw materials), and center of mass. In the case of analysis of archaeological materials, the 3D-scanning method shows clear advantages over others, since it offers the possibility of accurate measurements of models and further verification of them.

As a result of comprehensive research, it has been established that all the morphological and technological characteristics of the ivory anthropomorphic figurine testify to its usage as a peculiar ornament to be sewn onto clothing:

1) the plano-convex shape of the sculpture intentionally fashioned by the artisan;

2) the presence of similarly-sized and symmetricallylocated holes;

3 ) an artificially preset direction of the axes of drilled holes: diagonal relative to the artifact's cross-section, the axes intersect at the point corresponding to the longitudinal plane of symmetry of the figurine;

4) the position of the item's center of mass, which ensured that the wearing of it on clothing was comfortable.

The stylistic features of all three anthropomorphic images show their common iconographic style. The discovery of two figurines in one grave, and the rare and valuable fabricating material from which they are manufactured, are indicative of the exclusive social status of the buried man. The shaping type of holes, and the position of the geometric center of mass on the studied ivory item, argue for the life-time use of this artifact. In our opinion, in the event of its manufacture for the burial rite, careful observance of the requirements for the center-of-mass position was not a functional or technological necessity.

\section{Acknowledgement}

This study was performed under R\&D Project No. 0264-20190009 "Digital Technologies in Reconstruction of Subsistence Strategies of the Ancient Eurasian Population".

\section{References}

\section{Basova N.V. 2018}

Keramika iz mogilnika bronzovogo vremeni na poselenii Turist-2 v Novosibirske. In Problemy arkheologii, etnografii, antropologii Sibiri i sopredelnykh territoriy, vol. XXIV. Novosibirsk: IAET SO RAN, pp. 209-213.

Basova N.V., Postnov A.V., Nesterkina A.L.,

Akhmetov V.V., Morozov A.A. 2017

Rezultaty okhranno-spasatelnykh raskopok na poselenii Turist-2 v Novosibirske v 2017 godu. In Problemy arkheologii, etnografii, antropologii Sibiri i sopredelnykh territoriy, vol. XXIII. Novosibirsk: IAET SO RAN, pp. 509-512.

\section{Bazaliysky V.I. 2007}

Drevneye iskusstvo Baikalskoy Sibiri. Zemlya Irkutskaya, No. 1 (32): 3-11.

\section{Bobrov V.V. 2015}

Mobilnoye iskusstvo Sibiri v perekhodnoye vremya ot epokhi kamnya $\mathrm{k}$ paleometallu. In Iskusstvo bronzovogo veka: Materialy Mezhdunar. simp. 15-19 apr. 2013 g. Stralsund, Germaniya. Novosibirsk: Novosib. Gos. Univ.; Berlin: German. Arkheol. Inst., pp. 8-18.

\section{Borodovsky A.P. 1995}

Obrabotka bivnya mamonta $\mathrm{v}$ epokhu paleometallov (po arkheologicheskim materialam yuga Zapadnoy Sibiri). In Arkheologiya vchera, segodnya, zavtra. Novosibirsk: Izd. Novosib. Gos. Ped. Univ., pp. 113-121.

\section{Borodovsky A.P. 1997}

Drevneye kostoreznoye delo yuga Zapadnoy Sibiri (vtoraya polovina II tys. do n.e. - pervaya polovina II tys. n.e.). Novosibirsk: Izd. IAET SO RAN.

\section{Borodovsky A.P. 2012}

Kostorezniye zagotovki Ust-Poluya (po materialam issledovaniy 2006-2011 gg.). In Arkheologiya Arktiki: Materialy mezhdunar. nauch.-prakt. konf. Yekaterinburg: Delovaya pressa, pp. 30-35.

\section{Chistyakov P.V., Kovalev V.S., Kolobova K.A.,}

Shalagina A.V., Krivoshapkin A.I. 2019

3D modelirovaniye arkheologicheskikh artefaktov pri pomoshchi skanerov strukturirovannogo podsveta. Teoriya i praktika arkheologicheskikh issledovaniy, No. 3 (27): 102-112.

\section{Counts D.B., Averett E.W., Garstki K. 2016}

A fragmented past: (Re)constructing antiquity through $3 \mathrm{D}$ artefact modelling and customised structured light scanning at Athienou-Malloura, Cyprus. Antiquity, vol. 90 (349): 206-218.

Dayet L., Erasmus R., Val A., Feyfant L.,

Porraz G. 2017

Beads, pigments and early Holocene ornamental traditions at Bushman Rock Shelter, South Africa. Journal of Archaeological Science: Reports, vol. 3: 635-651.

Derevianko A.P., Shunkov M.V., Fedorchenko A.Y.,

\section{Kozlikin M.B. 2018}

Paleoliticheskaya diadema iz Denisovoy peshchery. In Problemy arkheologii, etnografii, antropologii Sibiri $i$ sopredelnykh territoriy, vol. XXIV. Novosibirsk: Izd. IAET SO RAN, pp. 87-90.

Devlet E.G., Laskin A.R., Svoisky Y.M.,

Romanenko E.V., Timofeeva A.S., Pakhunov A.S. 2017

Trekhmernoye dokumentirovaniye - instrument peredachi ikonograficheskikh osobennostey lichin v naskalnom iskusstve Dalnevostochnogo regiona. In Arkheologiya Circum-Pacific: Pamyati Igorya Yakovlevicha Shevkomuda. Vladivostok: Rubezh, pp. 264-271.

\section{Drozdov N.I. 1974}

Kodinskoye pogrebeniye s antropomorfnymi figurami iz bivnya mamonta. In Drevnyaya istoriya narodov yuga Vostochnoy Sibiri. Irkutsk: Izd. Irkut. Gos. Univ., pp. 229-236.

\section{Fedorchenko A.Y. 2018}

Paleoliticheskiye kamenniye ukrasheniya kulturnogo sloya VI Ushkovskikh stoyanok: Kontekst, tekhnologii, funktsii. Uralskiy istoricheskiy vestnik, No. 2 (59): 115-123. 


\section{Fedorov S.E. 2017}

Istoriya issledovaniy mlekopitayushchikh chetvertichnogo perioda v Yakutii (XVIII-XX vv.): Cand. Sc. (Biology) Dissertation. Yakutsk.

Freidline S.E., Gunz P., Janković I., Harvati K.,

Hublin J.J. 2012

A comprehensive morphometric analysis of the frontal and zygomatic bone of the Zuttiyeh fossil from Israel. Journal of Human Evolution, vol. 62: 225-241.

Girya E.Y. 2015

Analiz nekotorykh rezultatov eksperimentalnotrasologicheskikh issledovaniy Zhokhovskoy stoyanki. In IV Severniy arkheologicheskiy kongress: Doklad, N.M. Chairkina (ed.). Khanty-Mansiysk, Yekaterinburg: Inst. Istorii i Arkheologii UrO RAN, pp. 28-36.

Grimaud V., Cassen S. 2016

De l'usage de la représentation tridimensionnelle pour documenter les architectures funéraires monumentales ornées du Néolithique de l'ouest de la France. Les Nouvelles de l'Archéologie, iss. 146: 23-27.

Grosman L., Ovadia A., Bogdanovsky A. 2014

Neolithic masks in a digital world. In Face to Face: The Oldest Masks in the World. Jerusalem: The Israel Museum, pp. 54-59.

Grosman L., Shaham D., Valletta F., Abadi I.,

Goldgeier H., Klein N., Dubreuil L., Munro N.D. 2017

A human face carved on a pebble from the Late Natufian site of Nahal Ein Gev II. Antiquity, vol. 91 (358): 1-5.

Grushin S.P., Kokshenev V.V. 2004

Zakhoroneniye s antropomorfnoy skulpturoy v Srednem Prichumyshye. In Aridnaya zona yuga Zapadnoy Sibiri v epokhu bronzy. Barnaul: Izd. Alt. Gos. Univ., pp. 35-48.

Heckel C., Wolf S. 2014

Ivory debitage by fracture in the Aurignacian: Experimental and archaeological examples. Journal of Archaeological Science, vol. 42: 1-14.

Hein W. 2018

Tusks and tools - experiments in carving mammoth ivory. L'Anthropologie, vol. 122 (3): 437-446.

Karasik A., Smilansky U. 2008

3D scanning technology as a standard archaeological tool for pottery analysis: practice and theory. Journal of Archaeological Science, vol. 35 (5): 1148-1168.

Khavrin S.V. 1997

Mogilnik Verkhniy Askiz I, kurgan 1. In Okunevskiy sbornik: Kultura. Iskusstvo. Antropologiya. St. Petersburg: Petro-RIF, pp. 65-79.

Khlopachev G.A., Girya E.Y. 2010

Sekrety drevnikh kostorezov Vostochnoy Yevropy i Sibiripriyemy obrabotki bivnya mamonta i roga severnogo olenya $\mathrm{v}$ kamennom veke (po arkheologicheckim i eksperimentalnym dannym). St. Petersburg: Nauka.

Kiryushin Y.F., Grushin S.P. 2007

Predmety mobilnogo iskusstva rannego bronzovogo veka Verkhnego Priobya. In Kamennaya skulptura i melkaya plastika drevnikh i srednevekovykh narodov Evrazii. Barnaul: Azbuka, pp. 22-25. (Tr. SAIPI; iss. 3).

\section{Kistenev S.P. 1992}

Rodinkskoye neoliticheskoye zakhoroneniye i ego znacheniye dlya rekonstruktsii khudozhestvennykh i esteticheckikh vozmozhnostey cheloveka v ekstremalnykh usloviyakh Krainego Severa. In Arkheologicheskiye issledovaniya v Yakutii: Trudy Prilenskoy arkheologicheskoy ekspeditsii. Novosibirsk: Nauka, pp. 68-83.

Kovalev A.A. 1997

Mogilnik Verkhniy Askiz I, kurgan 2. In Okunevskiy sbornik: Kultura. Iskusstvo. Antropologiya. St. Petersburg: Petro-RIF, pp. 80-112.

Krivoshapkin A., Shalagina A., Baumann M., Shnaider S., Kolobova K. 2018

Between Denisovans and Neanderthals: Strashnaya cave in the Altai mountains. Antiquity, vol. 92 (365): 1-7.

\section{Kubarev V.D. 1988}

Drevniye rospisi Karakola. Novosibirsk: Nauka.

Levoy M., Pulli K., Curless B., Rusinkiewicz S.,

Koller D., Pereira L., Ginzton M., Anderson S.,

Davis J., Ginsberg J., Shade J. 2000

The digital Michelangelo project: 3D scanning of large statues. In Proceedings of the 27th Annual Conference on Computer Graphics and Interactive Techniques. Stanford: ACM Press, New York: Addison-Wesley Publishing Co, pp. 131-144.

Lipsky A.N., Vadetskaya E.B. 2006

Mogilnik Tas-Khazaa. In Okunevskiy sbornik: Kultura i eye okruzheniye. St. Petersburg: EleksisPrint, pp. 9-52.

MacDonald G.M., Beilman D.W., Kuzmin Y.V.,

Orlova L.A., Kremenetski K.V., Shapiro B.K.,

Wayne R.K., Van Valkenburgh B. 2012

Pattern of extinction of the woolly mammoth in Beringia. Nature Communications, No. 3. URL: https://doi.org/10.1038/ ncomms 1881

Makarov S.S. 2013

Dinamika kulturnogo razvitiya i osvoyeniye ZapadnoSibirskoy ravniny v pozdnem pleistotsene. Vestnik Novosibirskogo gosudarstvennogo universiteta. Ser.: Istoriya, filologiya, vol. 12. Iss. 7: Arkheologiya i etnografiya: 64-76.

McPherron S.P., Gernat T., Hublin J.J. 2009

Structured light scanning for high-resolution documentation of in situ archaeological finds. Journal of Archaeological Science, vol. 36: 19-24

Molodin V.I. 1977

Epokha neolita i bronzy lesostepnogo Ob-Irtyshya. Novosibirsk: Nauka.

Molodin V.I. 2015

Scepters of the developed Early Bronze Age in the south of Western Siberia (Iconography and Semantics). In Iskusstvo bronzovogo veka: Materialy Mezhdunar. simp. 15-19 apr. 2013 g. Stralsund, Germaniya. Novosibirsk: Izd. Novosib. Gos. Univ.; Berlin: Germ. Arkheol. Inst., pp. 189-210.

Morris C., Peatfield A., O’Neill B. 2018

'Figures in 3D': Digital perspectives on Cretan Bronze Age Figurines. Open Archaeology, vol. 4: 50-61.

Okladnikov A.P. 1955

Neolit i bronzoviy vek Pribaikalya. Pt. 3: Glazkovskoye vremya. Moscow, Leningrad: Izd. AN SSSR.

Pauls E.D. 1977

Dva okunevskikh pamyatnika na yuge Khakasii. In Okunevskiy sbornik: Kultura. Iskusstvo. Antropologiya. St. Petersburg: Petro-RIF, pp. 123-127.

Petrin V.T. 1986

Paleoliticheskiye pamyatniki Zapadno-Sibirskoy ravniny. Novosibirsk: Nauka. 
Pitulko V.V., Pavlova E.Y., Nikolsky P.A. 2015

Obrabotka bivnya mamonta $\mathrm{v}$ verkhnem paleolite Arkticheskoy Sibiri (po materialam Yanskoy stoyanki). Stratum plus: Arkheologiya i kulturnaya antropologiya, No. 1: 223-283.

Ponarin Y.P. 2009

Elementarnaya geometriya. Vol. 3: Treugolniki i tetraedry. Moscow: MTNMO.

\section{Savinov D.G. 2015}

Stratigrafiya okunevskogo iskusstva. In Iskusstvo bronzovogo veka: Materialy Mezhdunar. simp. 15-19 apr. $2013 \mathrm{~g}$. Stralsund, Germaniya. Novosibirsk: Novosib. Gos. Univ.; Berlin: German. Arkheol. Inst., pp. 19-53.

Shunkov M.V., Fedorchenko A.Y., Kozlikin M.B. 2017

Braslet iz bivnya ranney stadia verkhnego paleolita iz Denisovoy peshchery. In Problemy arkheologii, etnografii, antropologii Sibiri i sopredelnykh territoriy, vol. XXIII. Novosibirsk: Izd. IAET SO RAN, pp. 255-258.

Sinitsyn A.A. 2016

Ranniy verkhniy paleolit Vostochnoy Evropy: Ukrasheniya i voprosy estetiki. In Verkhniy paleolit: Obrazy, simvoly, znaki: Katalog predmetov iskusstva malykh form i unikalnykh nakhodok verkhnego paleolita iz arkheologicheskogo sobraniya $M A E R A N$, G.A. Khlopachev (ed.). St. Petersburg: Ekstraprint, pp. 320-337.

\section{Steguweit L. 2015}

Rotten ivory as raw material source in European Upper Palaeolithic. Quaternary International, vol. 361: 313-318.

\section{Targ S.M. 1986}

Kratkiy kurs teoreticheskoy mekhaniki: Uchebnik dlya vtuzov. [10th edition, amend. and suppl]. Moscow: Vysh. shk.

White R. 2007

Systems of personal ornamentation in the Early Upper Palaeolithic: Methodological challenges and new observations. In Rethinking the Human Revolution, P. Mellars, K. Boyle, O. Bar-Yosef, C. Stringer (eds.). Cambridge: McDonald Institute Monographs, pp. 287-302.

Wood J., Chapman G. 1992

Three-dimensional computer visualization of historic buildings - with particular reference to reconstruction modelling. Archaeology and the Information Age: A Global Perspective. London: HarperCollins, pp. 123-146.

\section{Zotkina L.V. 2019}

On the methodology of studying palimpsests in rock art: The case of the Shalabolino rock art site, Krasnoyarsk Territory. Archaeology, Ethnology and Anthropology of Eurasia, vol. 47 (2): 93-102.

\section{Zotkina L.V., Kovalev V.S. 2019}

Lithic or metal tools: Techno-traceological and 3D analysis of rock art. In Digital Applications in Archaeology and Cultural Heritage, vol. 13. URL: https://doi.org/10.1016/j.olaach.2019. e00099

Received March 14, 2019.

Received in revised form April 15, 2019. 